\title{
How Impartialist is the Utilitarian Principle of Utility?
}

\author{
Okorie, Ndukaku Ph.D. \\ Badejo, Omobola Olufunto Ph.D. \\ Department of Philosophy \\ Obafemi Awolowo University \\ Ile-Ife \\ Nigeria
}

\begin{abstract}
Utilitarianism as a normative theory for moral justification is Universalist and impartialist in the sense that it extends equal moral concern and treatment to all living human persons. It finds its justification on the principle of utility, otherwise known as "the greatest happiness principle". The principle holds that an action is right if it promotes the greatest amount of good over evil for the greatest number of people concerned with, or affected by the action, otherwise wrong. How impartialist is this principle? Our aim in this paper is to demonstrate a partialist interpretation of the utilitarian principle of utility. This implies first, that the principle is partialist and impartialist at the same time. Secondly, it also implies that there is partiality in utilitarianism as a theory of moral evaluation. From the arguments I supply to justify these claims, we draw the implication that utilitarian principle of utility is capable of justifying partialist and impartialist actions.
\end{abstract}

\section{Introduction and Preliminary Remark}

The utilitarian principle of utility or the Greatest Happiness Principle states that:

By the principle of utility is meant that principle which approves or disapproves of every action whatsoever, according to the tendency which it appears to have to augment or diminish the happiness of the party whose interest is in question. ${ }^{1}$

This is the original formulation of the principle of utility as an impartialist principle by Jeremy Bentham. This principle has been presented and adjudged by scholars to be impartialist. ${ }^{2}$ We disagree with this view. We aim to defend the view that a partialist interpretation of the utilitarian principle of utility is possible. That is, contrary to the view that the principle could only be impartialist, we intend to argue that it is also partialist. Does the universalist understanding of utilitarianism mean that it can only justify impartial actions? In other words, can the theory also justify partialist actions? In this paper, we aim to demonstrate that the principle of utility can justify both types of actions. To establish this, we will focus on the utilitarian principle of utility that states that an action is morally right if it promotes the greatest amount of good over evil for the greatest number of people concerned with, or affected by the action, otherwise wrong. The principle, as stated, is presumed to be impartialist. We aim to establish that the principle is partialist. This leads to two implications: (i) the principle will be partialist and impartialist at the same time; (ii) there is partiality in utilitarianism as a theory of moral evaluation. In ethical discourse, utilitarianism in general and the principle of utility, in particular, has been presumed to be impartialist and can only justify impartialist actions. However, it has not been adequately demonstrated that the principle of utility has partialist interpretation and consequently justifies partialist actions, which will lead to the two implications pointed above.

In ethical literature, the principle of utility has been interpreted and presented as universalist and impartialist that stands apart from moral partialism or particularism. The argument underlying moral universalism undertakes to establish that every moral agent deserve equal moral treatment (Gewirth, 1998: 287). Contrary to this view, we aim to argue that the principle of utility also has partialist interpretation. This is often overlooked, whereas it matters. It is important because seeing the partialist aspect of the principle of utility will enhance a better understanding of the principle in particular, and utilitarianism in general, thereby assisting agents in moral evaluations. Also, it will open up a new way of viewing utilitarianism as a theory of moral justification of human actions, especially among decision makers. In presenting the argument of this paper, we will not be discussing everything about utilitarianism. I will be focusing on the principle of utility. By establishing the partialist nature of the utilitarian principle, we would have established the partialism in utilitarianism. Moral partialism and impartialism has been presented as

\footnotetext{
${ }^{1}$ Jeremy Bentham, The Principles of Morals and Legislation, Buffalo: Promethens, 1988, p.2.

${ }^{2}$ Jeremy Bentham, An Introduction to the Principles of Morals and Legislation, Buffalo: Prometheus, 1988. John Stuart Mill in Utilitarianism and Peter Singer in Practical Ethics, as utilitarians and impartialists also held this view.
} 
two poles apart. This paper argues that there is partialism in impartialism by demonstrating the partialism in the utilitarian principle of utility.

Moral impartialism is concerned with the problem of how to justify the various human moral choices and decisions. The utilitarian principle of utility sets universal standard of evaluation, hence adjudged to be impartialist. Generally, universalist-impartialist theories or principles possess the following features: (i) Moral principles are universal and apply to all people, regardless of particular circumstances such as race, tribe, religion, nationality, among others; (ii) All human beings are capable of reason (reasoning is a universal phenomenon); (iii) All human beings are equal and deserve equal moral worth or treatment; (iv) Human nature or humanity is one and the same; and (v) All human beings are capable of feeling of happiness and pain anytime, anywhere. Universalism has been contrasted with particularism, such that while universalism affirms human moral equality, particularism denies it, by endorsing moral partiality. Particularism advocates preferential treatment or consideration to the interests of some persons as against others (Gewirth, 1988:283). It endorses the possibility of human differential or preferential treatment as against human moral equality and treatment.

Excluding the introduction and the conclusion, the paper is divided into two major sections. In the first section, a critical discussion of the impartialist nature and features of the utilitarian principle of utility is carried out. This section establishes the impartialism in the utilitarian principle of utility by critically examining its criterion of moral rightness and wrongness of actions. The second section examines the partialist interpretation or reconstruction of the principle of utility. Different examples will be used to illustrate this claim, pointing out the partialism in the principle of utility. This is with a view to showing that though the utilitarian principle of utility is adjudged impartialist, also has partialist interpretation and implication. Our view indicates that there is partialism in the principle of utility, notwithstanding its impartialist claims. Implicitly, there is partialism in utilitarianism, even as a universalist and impartialist ethical theory.

\section{On the Impartialist Nature of the Utilitarian Principle of Utility}

Ethical utilitarianism as a normative moral theory manifests its moral impartialism in the utilitarian principle of utility. It belongs to the consequentialist family of moral theories. This implies that in determining the moral rightness or wrongness of human actions, consequences of actions serves as the ultimate guide or yardstick. Consequences in this sense comprise the positive and negative consequences. Utilitarianism attempts to answer or respond to the general normative question 'how ought I to live?', 'how can I be happy?' It involves substantive proposals concerning how to act, how to live, or what kind of person to be. In particular, it attempts to state and defend the most basic principles governing these matters. ${ }^{3}$ Ethical utilitarianism is a theory about how we should act from the standpoint of morality. Like other normative theories, it spells out which ways of living are morally right and wrong, good and bad. ${ }^{4}$ Utilitarianism makes proposals about a morally right or wrong action, good or bad action through the principle of utility. That is, according to the utilitarians, the principle of utility defines or sets out the modalities or criteria of a morally right or wrong action.

What is the principle of utility? What does it say? How does it define morally right or wrong actions? How impartialist is it as a moral principle, anyway? The earliest formulation of the utilitarian principle of utility could be traced back to Jeremy Bentham. According to him, an action is right if it favours the greatest number of people. Bentham is regarded as the first systematic proponent of utilitarianism as an ethical theory. In his word, "it is the greatest happiness of the greatest number that is the measure of right and wrong". The focus is on how to produce more good over evil for the greatest number of people that will be affected by the action. The principle of utility holds that an action is right if it promotes the greatest amount of pleasure or happiness for the greatest number of people affected or concerned by the action, otherwise wrong.

In Bentham's view, moral agents' choices and decisions ought to aim at the actualization of the happiness or pleasure of everyone concerned or affected by the action. Thus, the utilitarian standard holds that an action is right if and only if it brings about at least as much net happiness as any other action the agent could have performed; otherwise it is wrong. In view of this, Bentham asserts that:

\footnotetext{
${ }^{3}$ Shelly Kagan, Normative Ethics, Oxford: West view Press, 1997, p.2. It is important to note that the task of attempting to state and defend the most basic principles governing how to live, how to act is not peculiar to ethical utilitarianism. It is the task before all normative theories- consequentialist, non-consequentialist (ethical deontology), and virtue theories. Each proposing its own criteria and standards of moral evaluation.

${ }^{4}$ Garrett Cullity, The Moral Demands of Affluence, Oxford: Oxford University Press, 2004, p.95.

5Jeremy Bentham, "A Fragment on Government" in the works of Jeremy Bentham, vol.1, ed. J. Bowring, New York: Russell and Russell, 1962, p.227. It is important to note that the phrase "the greatest happiness of the greatest number" is not original to Bentham. Such ethical view and formulation was prominent in some eighteenth century philosophers' work. For example, Francis Hutcheson's AnInquiry into the Original of Our Ideas of Beauty and Virtue: In two treatises, London: Midwinter, 1738, p.177.
} 
Nature has placed mankind under the governance of two sovereign masters-pain and pleasure. They alone point out what we ought to do and determine what we shall do; the standard of right and wrong, and the chain of causes and effects, are both fastened to their throne. They govern us in all we do, all we say, all we think; every effort we can make to throw off our subjection to pain and pleasure will only serve to demonstrate and confirm it. A man may claim to reject their rule but in reality he will remain subject to it (1988: 3)

Going by Bentham's view above, pain and pleasure are inexorable phenomena in human nature and condition. The task before human beings is to embrace pleasure and work as hard as possible to avoid pain. With this, utilitarians are not just interested in the positive results of actions but in the overall outcome because the two must be compared in order to decide the rightness or wrongness of human actions. The rightness of an action is decided in comparison with the total outcome, not only the good ones or bad ones, neither it is in piecemeal.

The initial problem with Bentham's formulations of utilitarianism has to do with the ambiguous nature of some of the words he employed. For example, the phrase "affected by the action" is ambiguous. How is the phrase to be understood? What exactly does Bentham mean by 'affected by'? There are myriads of ways an action could affect an individual. An action could affect someone psychologically, emotionally or physically. Bentham and his fellow utilitarians did not pay attention to this, hence did not specify in what sense they made use of the phrase. Also, pain could be physical or psychological.Does physical and psychological pain have equal status? In terms of degree, the two may not have equal status but Bentham and other utilitarians treat them as such.

As a result of the above, ethical utilitarianism is a theory of the personal good, that embodies interpersonal comparison. It is a theory of distributive indifference about the good. ${ }^{6}$ This brings out the impartialism in the utilitarian principle of utility. In moral evaluations, it is expected that all the individuals or groups involved in any moral outlook should be considered equally. Everyone matters equally. This brings out the principle of equal consideration of interests. In doing this, nobody's interest should be given more or special weight. This is because the principle of utility proposes and defends equal consideration of interests. This makes it impartialist.

How does the principle of utility do this? It first specifies some principles for ranking overall states of affairs from best to worst from an impersonal point of view. This impersonal point of view is assumed to be independent of every moral agent's point of view. It is a view that is detached from individual particular point of view. This impersonal point of view is seen as impartial point of view whereby everybody's interest counts equally. The principle of utility does not embody judgments about which overall states of affairs are best for particular individuals, but rather judgments about which states of affairs are best, all things considered, from an impartial standpoint. This impartial standpoint is taken to be universal because it must apply to everyone equally.No one ought to be given a different treatment from others. This is impartialist of the principle.

The point utilitarians are making is that the greatest happiness of the greatest number of people is the ultimate end of morality. The principle of utility is meant to achieve this. This is how impartialist the principle is. It does not take cognizance of the individual's sense of self-worth. The individual's interpersonal difference does not matter morally. It is so because it does not matter how happiness or pleasure is being generated. The principle of utility being stated this way has been accused and criticized of leading to extreme or rigorous impartialism.

For example, Cottingham argued that the principle will not only be "wholly unpalatable". It is, moreover, probably self-defeating. For it is far from clear that the cold and impersonal pursuit of global utility is in fact the optimum way for mankind to secure the highest possible level of happiness."' The point in this paper is not to argue for the efficacy or otherwise of the principle of utility in achieving the greatest happiness for the greatest number. The point is about the impartialist nature of the principle of utility. The principle is impartialist because it aims at generating happiness for everyone when everyone's happiness counts for one, and none for more than one.

Cottingham could be understood to be saying that even if the production and pursuit of the greatest happiness is the goal of morality, it is still not clear that moral impartialism is the best route or avenue for achieving such. This, in another sense raises doubt whether the principle of utility is really impartialist. But in order to clear such doubt, Brian Feltham in discussing the principle explains that “....for a utilitarian, each person's good figures only for its impartial worth, measured on a fair scale and summed with the rest." ${ }^{\prime 8}$ He buttressed this with a paragraph from Mill's Utilitarianism which holds that the utilitarian principle would be "a mere form of words without rational signification, unless one person's happiness... is counted for exactly as much as another's." $W$ What this implies is

\footnotetext{
${ }^{6}$ James Wood Bailey, Utilitarianism, Institutions, and Justice, Oxford University Press, 1997, p.3.

7 John Cottingham, “The Ethics of Self-Concern”, Ethics, Vol. 101, No.4, (July 1991), p.803.

${ }^{8}$ Brian Feltham, Introduction: "Partiality and Impartiality in Ethics" in Brian Feltham and John Cottingham (eds.), Partiality and Impartiality, Morality, Special Relationships, and The Wider World, 2010, p.19.

${ }^{9}$ John Stuart Mill, Utilitarianism, in Mary Warnock (ed.), London: Fontana Press, 1962, Chapter v, paragraph 36 , p. 319. 16
} 
that an individual's point of view becomes necessary and important as long as it contributes to the impartial evaluation of the moral outlook which will lead to the aggregated happiness. This interpretation is exemplified in Mill's formulation of the principle as stipulating that "actions are right in proportion as they tend to promote happiness, wrong as they tend to produce the reverse of happiness." ${ }^{.10}$ The target is to produce more happiness and an individual's happiness matters only to the extent that it contributes to the net happiness of everyone involved in the action. This is for the sake of moral impartialism. When an individual agent's well-being or happiness does not contribute to the aggregated welfare, it becomes irrelevant. It is important to quickly point out that an individual's choice neglected on the ground that it does not contribute to the general welfare or happiness amounts to the demonstration of moral partiality. This is because the agent's interest matters to him as much as other people's interests matter to them. His or her personal interest should not be overridden by the overall interests for the sake of moral impartialism.

Moreover, Mill is also of the view that the principle of utility is intuitively obligatory, such that intuitive ethics coincide with the utilitarian ethics without quarrel. One of the implications of the obligatoriness of the principle of utility is the obligatoriness of moral impartialism. In this regard, Mill maintains that if the belief in the transcendental origin of moral obligation gives any additional efficacy to the internal sanction, it appears that the utilitarian principle has already the benefit of it. ${ }^{11}$ Mill uses this to justify the moral obligatoriness of the principle of utility, and consequently the moral obligatoriness of moral impartialism (that depends on it), as an ethical point of view. The principle of utility as an impartialist principle enjoins us to count each person affected by our actions as one and none for more than one. This justifies the impartiality of the utilitarian principle.

Among utilitarians, moral impartialism has been viewed as a necessary and fundamental component of moral deliberation and evaluation, such that in assessing any moral action, impartialism as a moral rule or principle should and must be recognized as the guiding principle. ${ }^{12}$ If impartialism is the guiding principle, it is assumed that everyone is taking care of equally because everyone matters equally as the principle of utility demands.

In summary, all utilitarians are impartialists. But not all impartialists are utilitarians. The evidence can be inferred from the views of some of the utilitarians discussed above. All utilitarians are impartialists because they adhere to the following impartialist minimum claims: (i) Morality demands that the moral point of view should be universal as well as moral assumption of equality of all human beings. (ii) Morality requires that we should not play favourites, or manipulate rules to our advantage, rather we should be impartial. (iii) The nature of moral deliberations, moral judgment, and moral evaluation requires us to adopt a point of view that is decided by not our own as moral agents because we are not the only people affected by our actions.

All utilitarians are impartialists because their views endorse the impartialist minimum claims outlined above. The utilitarian principle of utility is impartialist because it holds that the same moral standard must be applicable to all the people affected by particular moral decision. All persons matter equally from the moral point of view.It emphasized that equal moral weight or concern should be accorded to every individual. These make the principle of utility universalist and impartialist. The principle is derived from the impartial assignment of value to people's interests. According to R.M. Hare, “...showing... equal concern by giving equal weight to the equal interests of everybody... is a precept which leads straight to Bentham's formular and to utilitarianism itself." 13 The principle of utility is the principle that best recognizes the equal worth of people's interests. It is an impartialist principle because it holds that the same moral standard must be applicable to all people affected by particular moral decision. This is in line with moral impartialism as a moral requirement. Hence, this brings out the impartialism in the utilitarian principle of utility.

The point is that for an action to be right it must adhere to the principle of utility, otherwise it is wrong. At one point in An Introductionto thePrinciples of Morals and Legislation, Bentham says:

\footnotetext{
${ }^{10}$ John Stuart Mill, Utilitarianism, Chapter ii, paragraph 2, p.257.

11 J. S. Mill, Utilitarianism, pp.29-30

${ }^{12}$ This view is manifested in Bentham and Mill as utilitarians, in their popular and equalitarian dictum of 'each to count as one and none for more than one'. They are of the view that this axiom should govern the distribution of happiness, and impartiality is essential in deciding between our own happiness and that of others. In the same vein, Henry Sidgwick in The Methods of Ethics, $7^{\text {th }}$ edition, Hackett Publishing Company, 1981, p.382, holds that, "the good of any one individual is of no more importance... than the good of any other". Also, Peter Singer in Famine, Affluence and Morality, Philosophy and Public Affairs, 1972, holds that "we must give equal weight in our moral deliberations to the like interests of all those affected by our actions. It is important to note that the impartialist thesis has been defended by Singer in several works, such as Practical Ethics.

${ }^{13}$ R.M. Hare, "Right, Utility and Universalization, Reply to J.L. Mackie" in Frey, ed; Utility and Rights, Minneapolis: University of Minnesota Press, 1984, p.107
} 
Of an action conformable to the principle of utility, one may always say either that it is one that ought to be done, or at least that it is not one that ought not to be done.

One may say also, that it is right it should be done; at least that it is not a wrong action, When thus interpreted, the words ought, and right and wrong, and others of that stamp have a meaning: when otherwise, they have none. ${ }^{14}$

With this assertion, Bentham's claim is that the ultimate criteria-specifying principle is the principle of utility. His claim is that in order for judgments and principles to count as moral, they must not only express our approval or disapproval, but must be governed ultimately by the utilitarian principle of utility that defines the concept of morality. It is only the principle that distinguishes moral judgments and principles from non-moral ones. In fact, Bentham's claim is that morality finds its content on the principle of utility. The principle of utility says that actions are right insofar as they tend to promote happiness, otherwise wrong. ${ }^{15}$ This view re-echoes Bentham's view.

So far, I have been trying to discuss the impartialist nature of the principle of utility as a universalist principle. This has been with particular reference to establishing how impartialist the utilitarian principle is. This is the first section of the paper. In the second section below, we will demonstrate the partialist interpretation or reconstruction of the utilitarian principle of utility.In doing this, I will show how utilitarianism is not totally devoid of partialism.

\section{The Partialist Interpretation of the Principle of Utility}

From the above discussion, the principle of utility is presented as an impartialist principle such that it justifies actions that are impartial. This is the way the principle has been interpreted and presented. But contrary to this view, this section aims to establish that the principle of utility is also partialist. The point we want to make is that there is also a perspective from which we can advance a partialist interpretation of the utilitarian principle. To this end, the main issues we address in this part of the paper is the partialist aspect of the utilitarian principle of utility.

The problem with the principle of utility is that it is not only impartialist actions that it can justify. The principle can justify partialist actions just in case those actions promote happiness or pleasure for the greatest number of people. To illustrate a case whereby the principle of utility can justify a partialist action, let us look at this example. In a football match between two teams: a foreign team and home team, if the foreign team plays better and deserves to win the match but does not have the support of the greatest number of people, who are otherwise the spectators, the referee can do something. The referee can award a penalty in favour of the home team. Assuming the home team scores the penalty, this will make the greatest number of people (spectators) happy. This will achieve the aim and target of utilitarian principle of producing happiness for the greatest number of people. The principle of utility would no doubt justify the referee's action because it makes the greatest number of people happy. The greatest number of people derives pleasure from such action; hence, it is a morally right action. The referee's action is partialist. It is a partialist action justified by the utilitarian principle. In this regard, the principle is partialist. Partialist actions are actions we take in general moral evaluations in order to favour certain individuals or groups who stand in a particular close or special relationships with us.

The point we can also make out from the above example is that an action could give happiness or pleasure to the greatest number of people in a particular moral deliberation and still remain partialist. For an action to be impartialist, does not necessarily depend on the greatest number of people involved or affected by an action as the utilitarians erroneously assumed. Utilitarians assumed that once the interests of the greatest number of people are satisfied, the action is impartialist and consequently morally right. This is not always the case, as exemplified by the above example.

The issue is that a partialist action could promote the happiness of the greatest number of people and consequently be justified by the principle of utility. It is not only impartialist actions that the principle of utility justifies.This is a typical example of a partialist action justified by the utilitarian principle of utility. But does this leads to a contradiction that an action is partialist and impartialist at the same time? In anticipation of this question, Idil Boran writes:

Any given procedure of impartial judgment presents a problem of exclusionary bias if and only if the judgment invokes a focal group. If the judgment presents a problem of exclusionary bias, then it has elements of partiality in it. A given procedure of impartial judgment invokes a focal group. Therefore, the impartial procedure has elements of partiality in it. This reasoning indicates that some impartial procedures are not fully impartial, but partly partial. This, however, is a contradiction. It is morally confusing and logically inconsistent to claim that a given judgment is impartial and partial at the same time. (2004: 336).

\footnotetext{
${ }^{14}$ Jeremy Bentham, An Introduction to the Principles of Morals and Legislation, Chapter 1, paragraph $\mathrm{x}$.

${ }^{15}$ John Stuart Mill, Utilitarianism, edited with an introduction by George Sher, Indiana: Hackett Publishing Company, 1979, p.7
} 
Moreover, how the utilitarians arrive or decide for their principle-the principle of utility may be said to be arbitrary. The utilitarians' choice of their principle is partialist itself. It is partialist because there are other principles that they could have chosen but they settled for the principle of utility, even as they claim it is impartialist.

The choice of the principle already presupposes alternatives since choices are not possible outside alternatives. Making choices among alternatives already presupposes partialism. This is because something is preferred over another. A particular view is favoured or preferred over others. Also, to be impartial presupposes that a position has already been taken. The reason is that a moral agent adopting an impartial position could have taken alternative view, for example, a partialist view or position but decided for an impartialist position, which is otherwise partialist.

An impartialist view defends and prefers a particular view- the impartialist view. This implies that by virtue of making choice out of alternatives, a preference or favourite choice has been made. This favour or preference for impartialism or the impartialist point of view is already partialist. This further shows that the utilitarians' choice of principle among other alternative principles is partialist. After all, utilitarians preferred the principle of utility over and above other principles. The act of showing favourite or preference already presupposes partialism.

Furthermore, the utilitarian principle of utility understood as a theory of moral standard of rightness, views right actions as those that maximize welfare. It recommends that in deliberating about what to do in particular moral cases, agents should figure out which action would maximize the welfare of the greatest number of people involved in the action. It follows from this, that once an action maximizes the welfare of the greatest number of people, the action is justified by the principle of utility. Consequently, if it is justified by the principle, then it is impartialist. Unbeknown to the utilitarians, the principle which is the hub of their theory could justify partialist actions. For example, an armed robber that robbed a bank but stand the risk of being caught might throw money to the teaming crowd because their presence impedes his or her movement. The crowd would be made happy by the action of the armed robber, at least for giving them money. What follows from this? The action is partialist. It is partialist because the armed robber wants to use it as an avenue to escape but the crowd would be made happy by it. The principle of utility will justify it, whereas it is a partialist action. This also demonstrates that the utilitarian principle of utility is partialist.

According to utilitarians and other impartialists, true ethical principles are those that an impartial moral agent or being would endorse. Following from this, an impartialist-utilitarian would endorse partialist principles, attitudes and conducts, provided that such actions are justified by the principle of utility. To illustrate this, an example will suffice. If we, as a moral agents is faced by two people about to drown: one of them, a brother and the other, a stranger. Let's say the stranger is a renowned medical doctor while our brother is a mere cleaner. If saving the stranger has more prospects of adding more value to the world or producing more happiness or pleasure in the world, the principle of utility would approve the action. In this case, moral impartialism is also justified because I did not consider my close and special tie or bond with my brother as a moral reason for saving him first.

However, we can as well save our brother without minding that saving the stranger will add more value- happiness or pleasure to the world. We can save my brother by considering the special and close relationship that bind us. It could be that saving our brother will add more value to the world than saving the stranger. If that is the case, the utilitarian principle of utility would justify our action. But by saving our brother, we did not see the more valuehappiness and pleasure he will add to the world as our motivating reason to act. We only consider our close tie and bond as our motivating reason, whereas it is justified by the principle of utility. This depicts that partialist action could be justified by the principle of utility. In this example, though it could be argued that our brother might add more value to the world, which is impartialist. Our perspective for saving our brother is because he has a blood relationship and close tie with us. This is a partialist reason for our action but justified by the principle of utility. It is justified by the principle of utility because we saved our brother on the basis of our relationship with him. It only turn out that saving him adds more value to the world but that was not our moral reason or motive for saving him. This demonstrates that the principle of utility has partialist interpretation.

According to the utilitarian principle of utility, between our brother and the stranger, no one is more valuable. The two of them have equal moral worth and deserve equal moral treatment. So, we must consider the stranger the same way we consider our brother. In doing so, the principle of utility justifies the action. However, when we consider our brother for a different reason (because he stands in a special relationship with us), the principle of utility also justifies the action. This supports the view that the principle, though an impartialist principle, also has partialist interpretation and justification. The utilitarians' aim of promoting the option that will add more value to the world is partialist. Why should the principle of utility hold on to a particular criterion of justification of moral actionspreferring the option that will add more value to the world and still lay claim to impartialism? This is no longer impartialist. It is rather partialist.

Another example to demonstrate the partialist interpretation of the principle of utility goes thus: If a moral agent stumbles on a bag on the road, with an identity card of the owner and a huge amount of money, what should s/he 
do? The moral agent has ten of his co-villagers dying of cholera, such that what they need to save their lives is exactly the same amount in the bag that the moral agent picked.

Should s/he trace the owner with the identity card and return the money, of which the owner would not accept to donate the money for the treatment of those ten cholera patients.

The two options before the agent are: (i) Either s/he returns the money to the owner, or (ii) s/he spends the money on the treatment of his or her co-villagers. If the moral agent returns the money to the owner, it will be a morally praiseworthy action (at least to a deontologist, such as Kant), but it will not be a morally right action for utilitarians. It will be a morally right action to the utilitarians if the moral agent will use the money for the treatment of the ten villagers, at least going by the principle of utility. Utilitarians will endorse it as a morally right action because treating the ten patients produces more good for the greatest number of people. This is in tune with the utilitarian principle of utility. In this case, the principle of utility justifies the action, even as a partialist action.

Moreso, the moral agent's motivating reason to use the money for the treatment of the ten villagers might not be because their lives will add more value to the world. His or her motivating reason for using the money to treat the ten cholera patients might just be that they are his or her co-villagers, hence they have existing relationship. The moral agent acts based on the existing relationship. Not only that they are his or her co-villagers, some of his or her brothers and cousins are among the ten patients. In this regard, s/he is acting from the perspective of the special and close relationships s/he has with those patients. This makes the action partialist. It is partialist, but the principle of utility justifies it because it will bring happiness for those people. In this regard, the principle of utility is therefore partialist.

The principle of utility also decides the rightness or wrongness of actions by looking at consequences or outcomes that result from such actions. Consequences are essential component of utilitarianism. If the action will lead to more beneficial consequences for the greatest number of people, the principle of utility justifies the action as a morally right action. The problem is that if the principle of utility decides the rightness of action by considering the beneficial consequences for the greater number of people over and above the lesser number of people, then it is partial, at least in favour of the greater number and against the lesser number. Partiality is partiality, whether in favour or against the lesser number.

The principle of utility favours beneficial consequences that will produce a greater net balance of satisfaction. By favouring or preferring one group or option when there are alternatives shows that the principle of utility endorses a partialist act. In this vein, ethical utilitarianism as an impartialist theory is also partialist. If it were not partialist, it would have considered everyone equally as it claims without resulting to making preference. This is because preference presupposes partiality.

\section{Conclusion}

In this article, we examined the partialist interpretation or reconstruction of the utilitarian principle of utility. The claim among utilitarians and other impartialists has been that the principle is impartialist. It is impartialist because it justifies impartialist actions by looking up to the satisfaction of the interests of the greatest number of people involved or affected by an action for deciding the morally right action. However, the paper challenged this claim. In challenging the claim, the paper argued that the utilitarian principle of utility no doubt has impartialist interpretation but also has partialist interpretations. But this has been neglected by the utilitarians and other impartialists. The paper is divided into two major sections.

The first section demonstrated the impartialist nature of the principle of utility. This became necessary because the paper claims that the principle is impartialist and partialist at the same time. The demonstration of partialist nature of the utilitarian principle is against the backdrop of its impartialist nature. The second section dealt with the partialist interpretation or reconstruction of the principle of utility with some concrete examples. In doing this, it was found that though the principle is impartialist, it is also partialist. Implicitly, this shows that the utilitarian principle of utility is not only partialist but that there is partialism in ethical utilitarianism as a moral theory of evaluation and justification.

\section{References}

Bailey, W. J. 1997. Utilitarianism, Institutions, and Justice. OxfordUniversity Press.

Boran, I. (2004). 'On Distinguishing Between Types of Impartiality'. The Journal ofValue Inquiry. 38:333-339.

Bentham, J. (1962). A Fragment on Government. Bowring, J. (ed.),. NewYork:Russell and Russell.

Bentham, J. (1988). The Principles of Morals and Legislation. Buffalo:Promethens

Cottingham, J. (1991). 'The Ethics of Self- Concern. Ethics. Vol.101, No.4, 798-817

Cullity, G. (2004). The Moral Demands of Affluence. Oxford University Press.

Feltham, B; Cottingham, J. (eds.). (2010). Partiality and Impartiality, Morality,Special Relationships, and the Wider World, Oxford University Press. 
Gewirth, A. (1988). 'Ethical Universalism and Particularism' The Journal ofPhilosophy. Vol.Lxxxv, No.6, 283302.

Gomberg, P. (1994). 'Universalism and Optimism'. Ethics. Vol.104, No.3, 536-557.

Hare, R. (1984). 'Right, Utility and Universalization, Reply to J.L. Mackie', Frey(ed.), Utility and Right. Minnesota Press.

Hutcheson, F. (1738). An Inquiry into the Original of Our Ideas of Beauty and Virtue:In two treatises. London: Midwinter.

Kagan, S. (1997). Normative Ethics. Oxford: West view Press.

Mill, J. S. (1962). 'Utilitarianism'. Mary Warnock (ed.). London: Fontana Press.

Sidgwick, H. (1981). The Methods of Ethics. Hackett Publishing Company.

Singer, Peter. (1972). 'Famine, Affluence and Morality'. Philosophy and PublicAffairs. Vol.2, No.3, 229-243.

Singer, P. (2011). Practical Ethics. Cambridge University Press.

Wolf, S. (1999). 'Morality and the view from Here'. The Journal of Ethics. Vol.3,No.3, 203-223. 